\title{
Strain survey on three continents confirms the polyphyly of the genus Pediastrum (Hydrodictyaceae, Chlorophyceae)
}

\author{
Mrutyunjay JenA ${ }^{1,2,3}$, Christina Bock ${ }^{1,4}$, Chhandashree BeHERA ${ }^{1,2}$, Siba P. AdHIKARY ${ }^{5}$ \\ \& Lothar KRIENITZ ${ }^{*}$
}

\author{
${ }^{1}$ Leibniz-Institute of Freshwater Ecology and Inland Fisheries, Alte Fischerhütte2, D-16775 Stechlin- \\ Neuglobsow, Germany; *e-mail: krie@igb-berlin.de, tel.: 033082 69926, fax: 03308269917 \\ 2 Department of Botany, Utkal University, Bhubaneswar-756014, Odisha, India \\ ${ }^{3}$ Department of Botany, Berhampur University, Berhampur-760007, Odisha, India \\ ${ }^{4}$ University of Essen, Faculty of Biology, D-45141 Essen, Germany \\ ${ }^{5}$ Department of Biotechnology, Visva-Bharati Santiniketan-731235, West Bengal, India
}

\begin{abstract}
Approximately 100 new strains of the Pediastrum-phenotype were isolated from inland waters of India, eastern and southwestern Africa, and Germany and were studied by light and scanning electron microscopy. The 18S rRNA and ITS genes of 28 strains were sequenced and compared with 25 sequences of Hydrodictyaceae from the GenBank database. Phylogenetic analyses confirmed the polyphyly of Pediastrum. The new species Sorastrum pediastriforme was described. This species resembled morphologically Pediastrum, however, the phylogenetic analyses revealed its affiliation within the genus Sorastrum. Furthermore, the following new combinations: Monactinus sturmii, Pseudopediastrum alternans, Pp. brevicorne, Pp. integrum, and $P p$. pearsonii were established.
\end{abstract}

Key words: CBC, ITS, Lacunastrum, Monactinus, morphology, Pediastrum, phylogeny, Pseudopediastrum, Sorastrum, SSU, Stauridium

\section{INTRODUCTION}

The family Hydrodictyaceae (Chlorophyceae) is from a morphological point of view, one of the most diverse natural lineages of coccoid green algae and comprises microscopic colonies of Pediastrum MEYEN, Euastropsis LAGERH. and Sorastrum KüTz. as well as macroscopic colonies of Hydrodictyon Rотн. Inspired by members of the genus Pediastrum, systematists have established more than 350 taxa (PARRA 1979). A flood of observations and revisions were published about Pediastrum and summarized by KOMÁREK \& FOTT (1983). The most recent review reduced the number of Pediastrum-species to 24 (КоMÁReK \& JANKOVSKÁ 2001). The other genera included smaller numbers of species: one of Euastropsis, seven of Sorastrum, and five of Hydrodictyon (according to KOMÁreK \& FotT 1983).

The first molecular phylogenetic studies including only two members of Hydrodictyaceae showed the close relationship of Hydrodictyon reticulatum (L.) LAGERH. and Pediastrum duplex Meyen (Wilcox et al. 1992; Lewis 1997) and their placement within Sphaeropleales (Buchнеiм et al. 2001). An expanded phylogenetic analysis of $26 \mathrm{~S}$ rRNA, 5.8S + ITS2 genes using sequences of seven strains of Hydrodictyon, 29 strains of Pediastrum and three strains of Sorastrum revealed a pattern of colony-form evolution within the family from twodimensionality to three-dimensionality (McManus \& LEwIS 2005). Another molecular phylogenetic study of 28 hydrodictyacean strains resulted in taxonomic revisions (BuchHeim et al. 2005). It was shown that the genus Pediastrum is of polyphyletic origin. Therefore, beside Pediastrum the genera Monactinus (TURPIN) E. Hegewald, Stauridium (Printz) E. Hegewald, Pseudopediastrum E. Hegewald and Parapediastrum E. Hegewald were delineated. Nevertheless, the number of strains analysed was very low, for example the genera Monactinus (formerly Pediastrum simplex) and Parapediastrum (P. biradiatum) were described from a single strain (BuchнeIM et al. 2005). Members of the unicellular genus Tetraedron Kürz. were linked phylogenetically to the Hydrodictyaceae (BuchнеIM et al. 2005; McManus \& Lewis 2005) however, the relative position was not clear from these analyses.

The morphospecies $P$. duplex was shown within different phylogenetic lineages of Hydrodictyaceae (McManus \& Lewis 2005). Therefore, one of these lineages was established as new genus Lacunastrum H. McManus (McManus et al. 2011). More detailed phylogenetic analyses based on 26S rRNA and $r b c \mathrm{~L}$ 
genes on $P$. duplex and its comparison to other members of Hydrodictyaceae were provided by Mc MANUs \& LEWIS (2011).

We have isolated ca. 100 strains of Hydrodictyaceae from three different continents - Africa, Asia and Europe - and studied them morphologically. From this collection, we subjected 28 strains to molecular phylogenetic analyses by sequencing the nuclear $18 \mathrm{~S}$ rRNA gene and ITS genes and the analyses confirmed the polyphyly of the genus Pediastrum. For species delineation, we applied the CBC concept (Coleman 2003). In the frame of this study we described the new species Sorastrum pediastriforme JENA, C. BOCK, BEHERA et KRIENITZ, and established five new combinations in the genera Pseudopediastrum and Monactinus.

\section{Material ANd Methods}

Algal cultures. About 100 unialgal strains of Pediastrumphenotype were isolated from field samples of inland waters of India, Israel, Kenya, Namibia, and Germany by microcapillaries and grown in a modified Waris solution (McFAdDEN \& MELKONIAN 1986). All strains were maintained at the algal strain collection of the Leibniz-Institute of Freshwater Ecology and Inland Fisheries (IGB) at Stechlin, Germany, and grown in suspensions at $15{ }^{\circ} \mathrm{C}$ under a $14: 10$ $\mathrm{h}$ light-dark regime. The strain of the newly described Sorastrum pediastriforme and the strains representing the five new combinations were deposited at the Culture Collection of Algae at the University of Göttingen (SAG, Germany).

Microscopy. The algae were examined using a Nikon Eclipse E600 light microscope (LM) with differential interference contrast. Photomicrographs (Figs 3-6) were taken with a Nikon Digital Camera DS-Fi1, and Nikon software NISElements D (Nikon Corporation, Tokyo, Japan). For scanning electron microscopy (SEM) the colonies of cultured material were fixed in $2.5 \%$ glutaraldehyde in culture medium for 30 min at $5{ }^{\circ} \mathrm{C}$, washed three times in $3 \mathrm{mM}$ Hepes buffer ( $\mathrm{pH}$ 7.0 ), and postfixed in $1 \%$ osmium tetroxide in a $1: 1$ mixture of $2 \% \mathrm{OsO}_{4}$ and $3 \mathrm{mM}$ Hepes for $1 \mathrm{~h}$. The fixed cells were then washed three times in Hepes buffer and dehydrated in a graded series of ethanol dilutions. Following dehydration, the material was dried at the critical point using aBALTEC CPD 030 critical point dryer (Balzers, Schalkmühle, Germany). Dried material was mounted on aluminium stubs, coated with gold/palladium by a Polaron CA 508 sputtercoater (Fisons Instruments, VG Microtech, Uckfield, UK) and examined under using the field-emission SEM Hitachi S-4500 (Hitachi Corporation, Tokyo, Japan) at $5 \mathrm{kV}, 10 \mu \mathrm{A}$.

DNA Isolation, PCR and Sequencing. A total of 28 strains were selected for molecular phylogenetic analyses. Algal cells were mechanically disrupted in the presence of glass beads $(\sim 0.5 \mathrm{~mm}$ in diameter, Carl Roth $\mathrm{GmbH}+\mathrm{Co} . \mathrm{KG}$, Karlsruhe, Germany) using the Retsch MM 2000 (Retsch, Hahn, Germany) bead disruptor. Total Genomic DNA was extracted according to KRIENITZ et al. (2012). The 18S rRNA and ITS -2 rRNA genes were amplified and sequenced as described by Bock et al. (2011). The newly sequenced strains were compared with 24 sequences of Hydrodictyaceae and one (outgroup) Scenedesmus-sequence from the GenBank database (National Center for Biotechnology Information [NCBI] http://www.ncbi.nlm.nih.gov/). The origin and accession numbers of all these 53 strains are listed in Table 1.

Phylogenetic analyses. Based on a concatenated data set (18S rRNA and ITS-2 rRNA) of 47 sequences with 1872 aligned base positions (excluding intron) phylogenetic analyses were performed. The Sequence alignment was done manually according to their secondary structure (COLEMAN 2003) using the SequentiX Alignment Editor (HepperLe 2004). The ITS-1 rRNA was not unambiguously alignable and was, therefore, excluded from the data set. In total, 28 strains that include representatives of the genera Pediastrum, Pseudopediastrum, Parapediastrum, Monactinus and Sorastrum were choosen from the GenBank database (National Center for Biotechnology Information [NCBI] http://www.ncbi.nlm. nih.gov/). The selection of additional sequences were done based on the publications of BuchHEIM et al. (2005) and McManus \& Lewis (2005, 2011). Scenedesmus obliquus UTEX 393 was selected as outgroup. The phylogenetic tree in Figure 1 was infered from a concatenated dataset using Treefinder (JoBB 2008). The applied models were chosen as proposed by Treefinder: For $18 \mathrm{~S}$ rRNA (1640 bases) the Tamura Nei model with Gamma distribution (TN:G:5), and for ITS-2 the transitional model with Gamma distribution (J2:G:5) were chosen.

To confirm the tree topology, bootstrap analyses were calculated by distance (neighbor-joining; NJ; 1000 replicates), parsimony (MP; 1000 replicates) using PAUP*, version 4.0b10 (SWOFFORD 2002) and maximum likelihood (ML; 1000 replicates; settings as described above) criteria. Bayesian inference (Bayesian posterior probabilities [BPP]; using the covarion model; 1 million generations) were calculated using MrBayes version 3.1 (HuElSENBECK \& RoNQUist 2001). The Bayesian analyses were carried out until the average standard deviations of split frequencies between two runs was lower than 0.01 . The first $25 \%$ of the calculated trees was discarded as burn-in. A 50\% majorityrule consensus tree was calculated for posterior probabilities (PP).

Secondary structures analysis. Secondary structures of ITS-2 were constructed with the help of mfold (ZUCKER 2003). The program 4SALE (SeIBel et al. 2006, 2008; SchultZ \& Wolf 2009) was used for comparision of ITS-2 among the strains to locate compensatory base changes (CBCs) including $\mathrm{Hemi}-\mathrm{CBCs}$ in the aligned ITS-2 sequences. The overview graphic was performed with PseudoViewer (BYUN \& HAN 2006). In order to find molecular criteria to discriminate the species, these secondary structures were checked for Compensatory Base Changes (CBCs) including Hemi-CBCs using 4SALE (SEIBEL et al. 2006, 2008).

\section{Results}

The concatenated set of 18S rRNA and ITS-2 sequences of 47 strains was included in the analyses to assess the phylogeny of Hydrodictyaceae. The 28 newly sequenced strains were placed in seven 
subclades of the phylogenetic tree (Fig. 1). Generally, the family of Hydrodictyaceae formed a monophyletic group well supported in the statistical analyses, only the ML analyses resulted in a lower bootstrap value of 67. Members of the genus Pediastrum sensu lato, which were in the focus of this study, were grouped into different lineages. According to suggestions of Buchнeim et al. (2005) these lineages were regarded as genera and designated as Pediastrum, Pseudopediastrum, Monactinus, Stauridium and Parapediastrum. Two strains belonged to the recently erected genus Lacunastrum (McManus et al. 2011). Hydrodictyon was closely related to Pediastrum, and Sorastrum is placed on the base of the tree as sister to all other hydrodictyacean subclades. The bootstrap support of different genera was high, only the Pseudopediastrum clade earned low support. The position of Tetraedron remained ambiguous.

The strain MJ 2008/46 (SAG 2392) from a dam near Nyahururu in Kenya clustered in the Sorastrum clade. Members of the genus Sorastrum normally, were characterized by three-dimensional colonies. However, the MJ 2008/46 (SAG 2392) strain showed flat coenobia (Figs 2a-d) resembling morphospecies of the genus Pediastrum, in particular those of $P$. duplex. Only few cells displayed a three-dimensional (tetrahedric) shape (Fig. 2d). This material was described as new species Sorastrum pediastriforme (see taxonomic conclusions).

Members of the genus Monactinus were found in India, Kenya and Germany. Whereas the strain from Germany exhibited the typical morphology of $M$. simplex var. simplex with large irregular holes within the coenobium (Figs 3a-b), the four tropical strains resembled M. simplex var. sturmii with stocky cells and smaller holes (Figs 3c-d).

Six new strains clustered in the Pseudopediastrum clade. These strains showed characteristic differences (Figs $4 \mathrm{a}-\mathrm{d}, 5 \mathrm{a}-\mathrm{d}$ ). Whereas the strains MJ 2008/33 and MJ 2008/35 from Lake Dollgow in Germany fully met the characteristics of Pseudopediastrum boryanum (TuRP.) MeneGh. (not shown), the others exhibited features of other taxa. Strain MJ 2008/83 from the river Cuando in Namibia possesses long conical lobes and deep incisions, resembling with Pseudopediastrum alternans Nyg. (Figs 4a-b). Strain MJ 2008/28 from Lake Dollgow in Germany had short lobes with shallow incisions and resembled Pp. boryanum var. brevicorne A. BRAUN (Figs 4c, d). Strain MJ 2008/86 from a pond in Namibia with short rounded apices and very shallow incisions resembled Pseudopediastrum integrum NäGELI (Figs $5 a, b)$. Strain KR 2006/01 from Lake Naivasha, Kenya, similar in morphology but different in molecular criteria, resembled Pp. integrum var. pearsonii (G.S. WeST) Fritsch (Figs 5c, d) known from tropical regions. Because of the clustering of these strains in the same clade, they all were considered as species of the genus Pseudopediastrum. For the essential new combinations see taxonomic conclusions.

Members of the former morphospecies Pediastrum duplex clustered in two different clades of the tree. Six of these strains remained in P. duplex, whereas two other strains were determined as Lacunastrum gracillimum (Figs 6a-d). These strains had relatively long processes and the ultrastructure of the cell wall was rippled, smooth, but not net-shaped and granular. These results confirmed the findings of McManus et al. (2011). Five new strains of Stauridium tetras (Ehrenb.) E. Hegewald from Kenya and India and S. privum (Printz) E. Hegewald from Kenya and Germany clustered in the clade of Stauridium. One strain of Parapediastrum biradiatum (Meyen) E. Hegewald from Germany clustered together with a strain from Sweden in the Parapediastrum clade. These results confirmed the findings of Висннеім et al. (2005).

To test the results of the topology of the phylogenetic tree, the secondary structure of the ITS-2 was studied, with the main goal to find CBCs and hemi$\mathrm{CBCs}$ associated with individual taxa. The secondary structure of the taxa studied exhibited the common pattern with four helices, in which the helix I was branched, shown here using Sorastrum pediastriforme (Fig. 7) as exemplar. To establish an overview, we made a pairwise comparison of the CBCs of the conserved regions of all helices between the species which were discovered to be the closest relatives to each other according to the tree. Sorastrum pediastriforme differs from S. spinulosum (UTEX 37) by 2 CBCs in Helix I (not shown). Monactinus simplex and M. sturmii differed by 2 CBCs and 5 or 6 hemi-CBCs in helix III (Table 2). The species of Pseudopediastrum differed in the following numbers of CBC (Table 3): $P p$. boryanum differed from $P$ p. kawraiskyi by 2 CBCs in helix III. Pp. alternans differed from Pp. brevicorne only by hemi-CBCs, 3 in helix I and 1 in helix III. $P p$. integrum differed from $P p$. kawraiskyi by $2 \mathrm{CBCs}$ in helix III. Pp. pearsonii differed from Pp. integrum by $1 \mathrm{CBC}$ in helix I and $1 \mathrm{CBC}$ in helix III (not shown).

\section{Discussion}

Our study confirmed the polyphyletic origin of members of the genus Pediastrum which was already shown by Buchieim et al. (2005) and McManus \& Lewis (2005). Furthermore, we confirmed the generic conception of Hydrodictyaceae and studied new strains from all genera of the relationship of Pediastrum sensu lato (Parapediastrum, Pseudopediastrum, Lacunastrum, Monactinus, and Stauridium) as well as Sorastrum. Generally, the differentiation between the genera of Hydrodictyaceae is validated by both, morphological and molecular criteria. However, an interesting example was uncovered contrasting with this general 


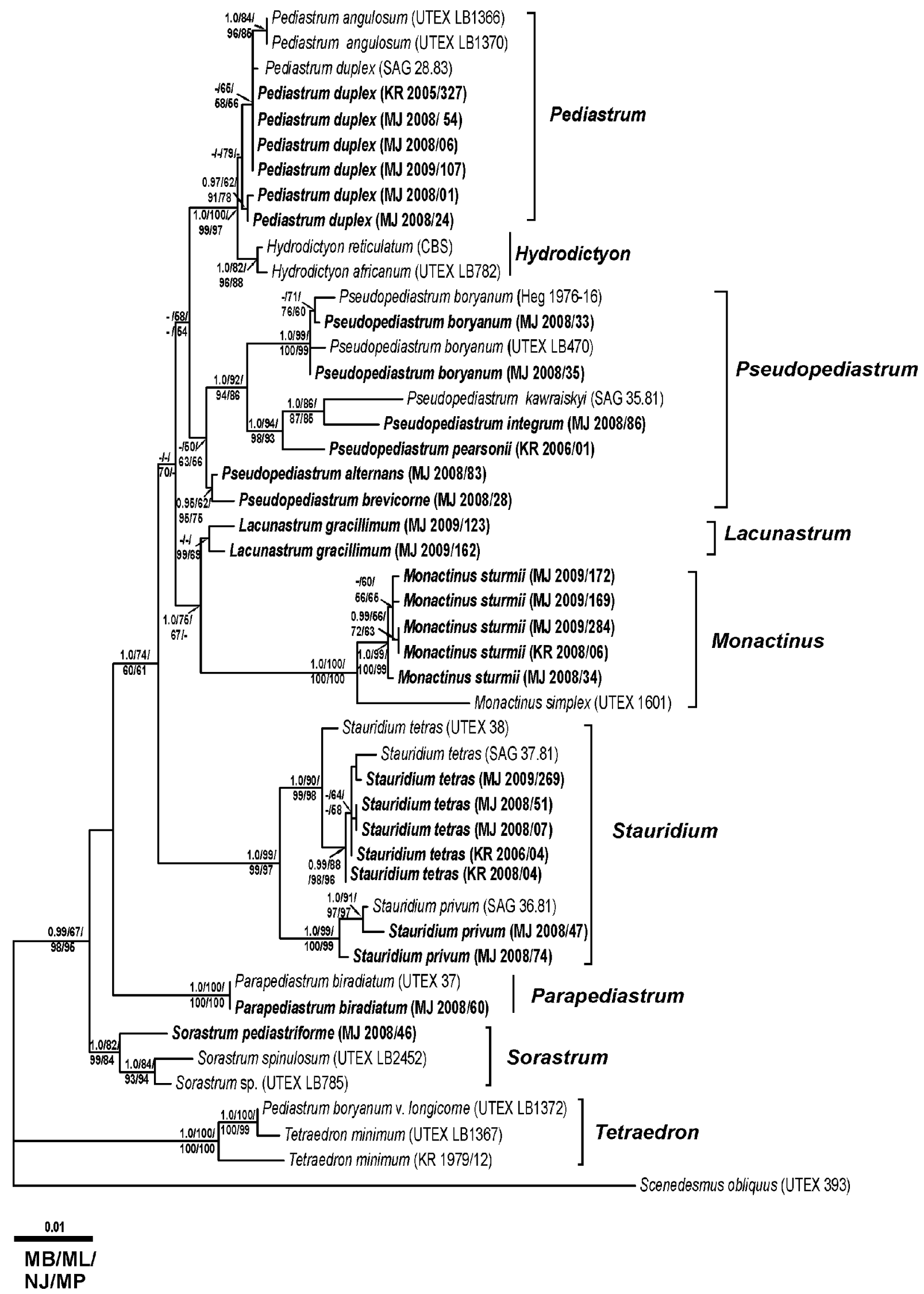

Fig. 1. Phylogeny according to the concatenated SSU and ITS-2 rRNA gene data set of the studied Hydrodictyaceae. Values at the nodes indicate statistical support estimated by four methods - Bayesian support (MB BPP), maximum likelihood (ML), maximum parsimony (MP) and neighbor joining (NJ). Hyphens indicate support below 50\% for ML, MP, NJ and below 0.95 for MB BPP. 

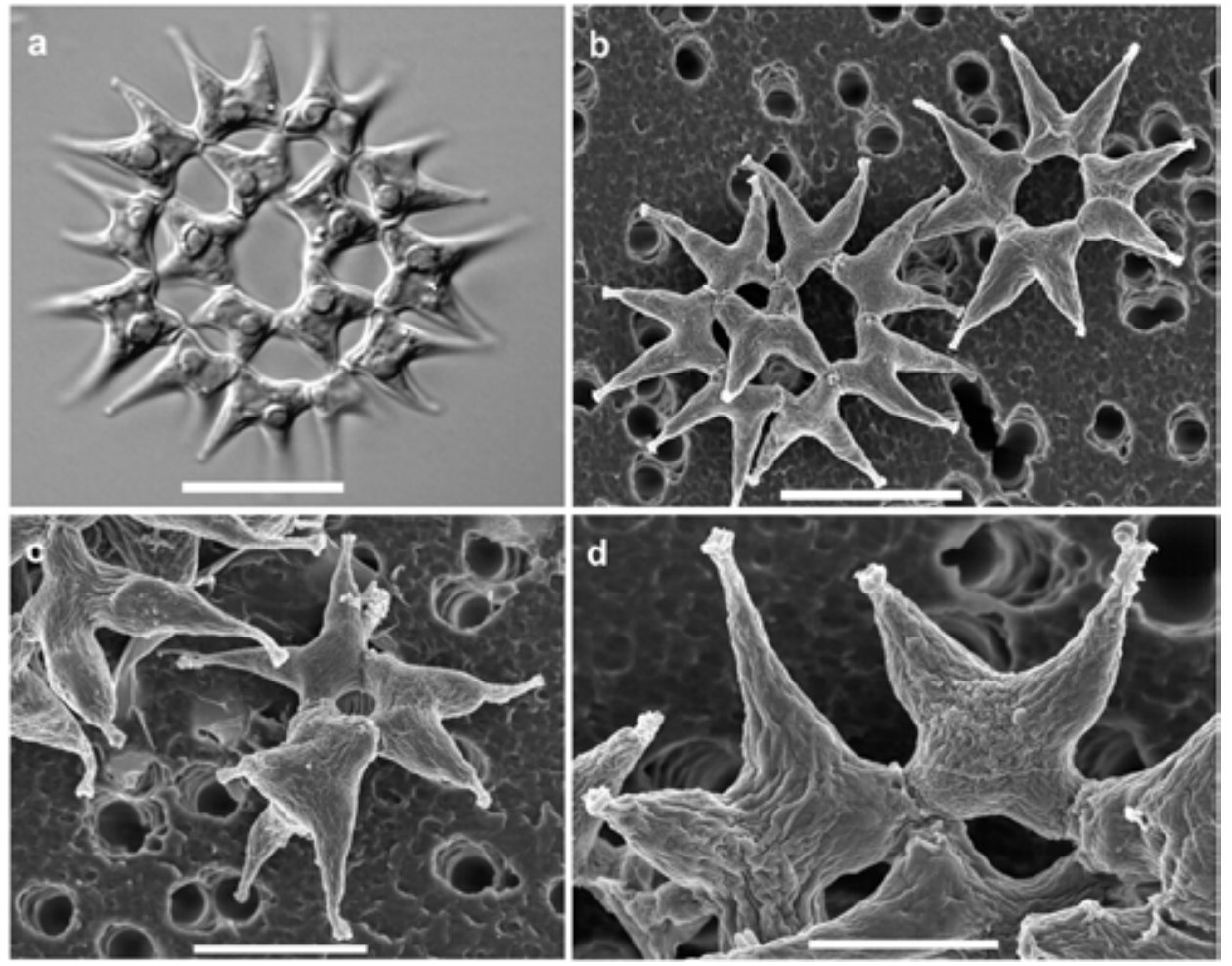

Fig. 2. Micrographs of Sorastrum pediastriforme (MJ 2008/46) in culture: (a) LM; (b-d) SEM. The arrow in (d) indicates a tetrahedric cell. Scale bar $2 \mu \mathrm{m}$ (a); $14 \mu \mathrm{m}$ (b); $6 \mu \mathrm{m}$ (c), $10 \mu \mathrm{m}$ (d).

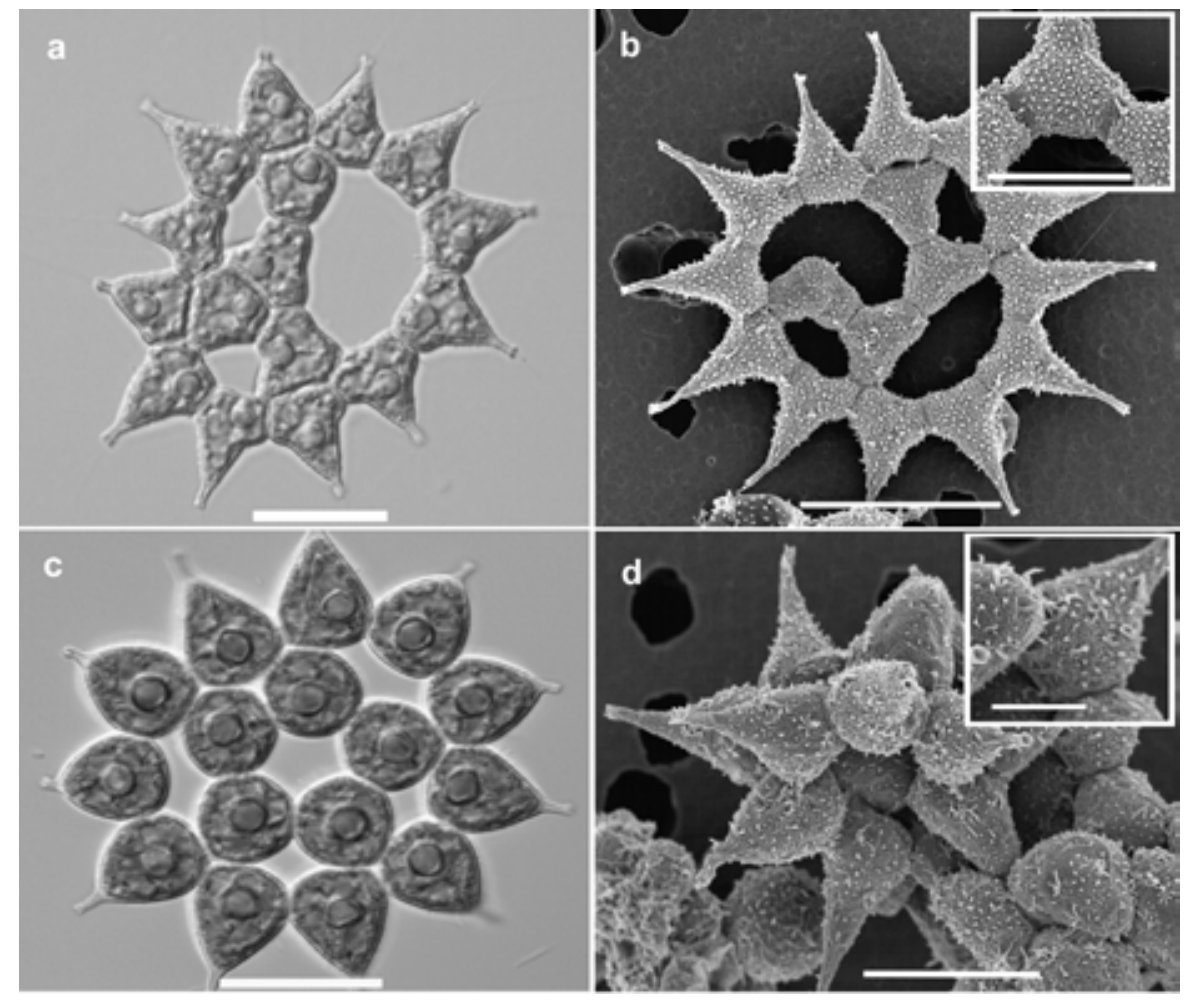

Fig. 3. Micrographs of Monactinus in culture: (a, b) M. simplex (MJ 2008/34); (c, d) M. sturmii (MJ 2009/172). Scale bar $10 \mu \mathrm{m}$ (a); $20 \mu \mathrm{m}$ (b); $15 \mu \mathrm{m}(\mathrm{c}, \mathrm{d})$. 

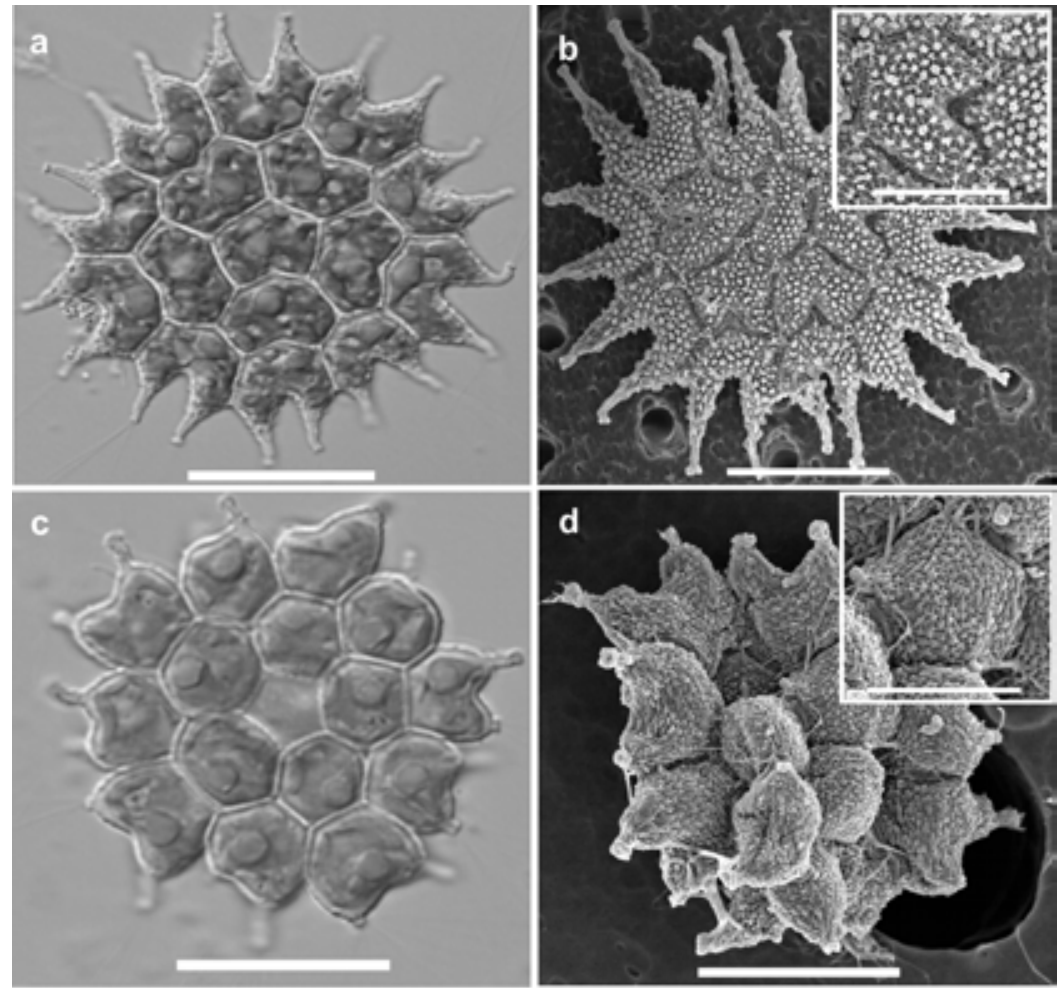

Fig. 4. Micrographs of different Pseudopediastrum strains: (a, b) Pp. alternans (MJ 2008/83); (c, d) Pp. brevicorne (MJ 2008/28). Scale bar $15 \mu \mathrm{m}(\mathrm{a}) ; 12 \mu \mathrm{m}(\mathrm{b}) ; 10 \mu \mathrm{m}(\mathrm{c}, \mathrm{d})$.
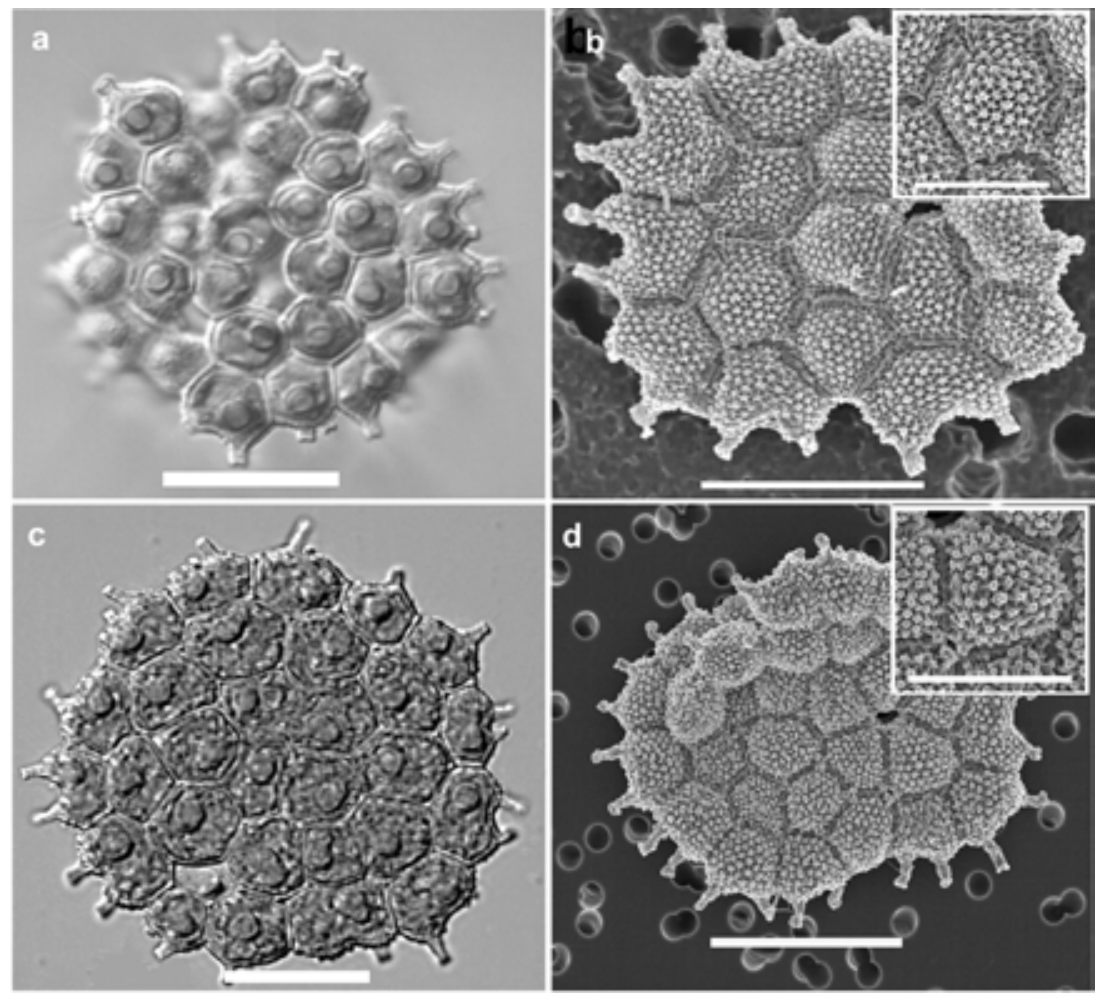

Fig. 5. Micrographs of different Pseudopediastrum strains: (a, b) Pp. integrum (MJ 2008/86); (c, d) P. pearsonii (KR 2006/01). Scale bar 12 $\mu \mathrm{m}(\mathrm{a}) ; 20 \mu \mathrm{m}$ (b); $10 \mu \mathrm{m}$ (c); $12 \mu \mathrm{m}$ (d). 

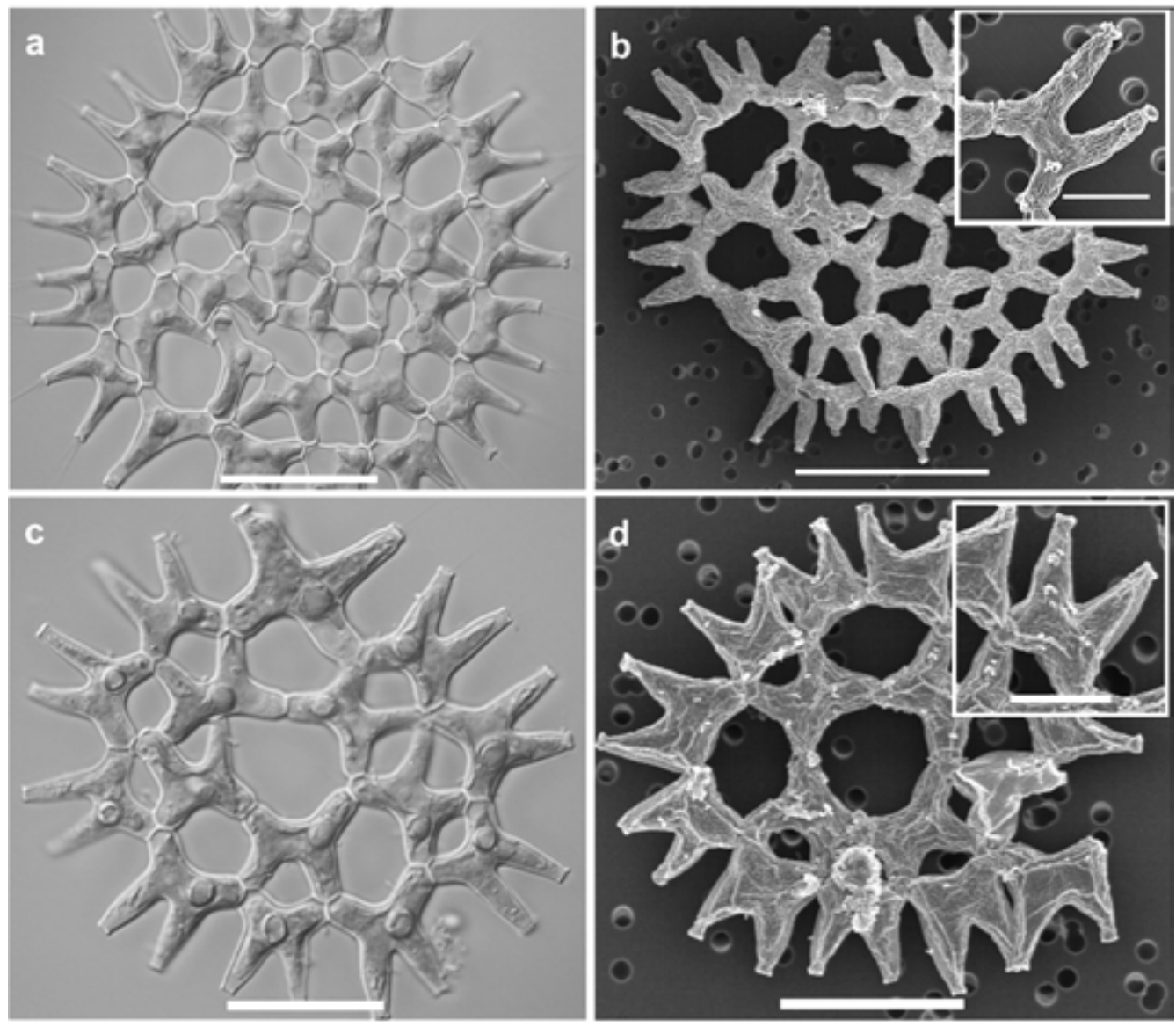

Fig. 6. Micrographs of Lacunastrum gracillimum strains: (a, b) MJ 2009/123; (c, d) MJ 2009/162. Scale bar $25 \mu \mathrm{m}$ (a); $36 \mu \mathrm{m}$ (b); $20 \mu \mathrm{m}$ (c); $22 \mu \mathrm{m}(\mathrm{d})$.

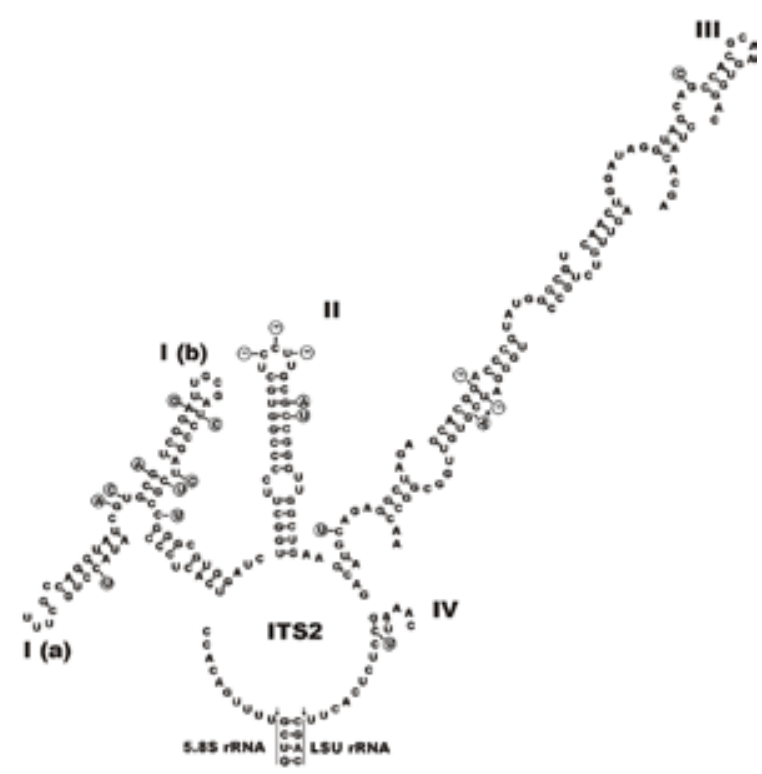

Fig. 7. Secondary structure of the ITS-2 of Sorastrum pediastriforme strain SAG 2392. Sorastrum spinulosum strain UTEX LB2452 as core struture, intraspecific base changes between strain SAG 2392 and UTEX LB2452 are marked in circles. view. The new species Sorastrum pediastriforme which morphologically resembles Pediastrum but molecular phylogenetic analyses reveals its alliance with Sorastrum.

Studying two strains of Lacunastrum gracillimum from India, we confirmed the polyphyly of the Pediastrum duplex phenotype revealed by McManus et al. (2005) and the delineation of the genus Lacunastrum by McMAnus et al. (2011). It was shown that phylogenetic findings sharpen the eyes for subsequent careful morphometric evaluation of diagnostic features to discriminate the two very similar phenotypes of $P$. duplex and L. gracillimum (McManus et al. 2011).

In the present state we are still working to clarify the interplay between morphology and phylogeny in Hydrodictyaceae with reference to the other two main clades of planktonic Chlorophyceae, the Scenedesmaceae and Selenastraceae. The interpretation of the state widely depends on exemplarily treated groups. In Scenedesmaceae an extraordinary level of morphological variability must be reconciled to a scarcity of molecular peculiarities such as compensatory base changes (VANORMELINGEN et al. 2007). On the other side, the relatively uniforme spindle-shaped phenotype of Acutodesmus represents 


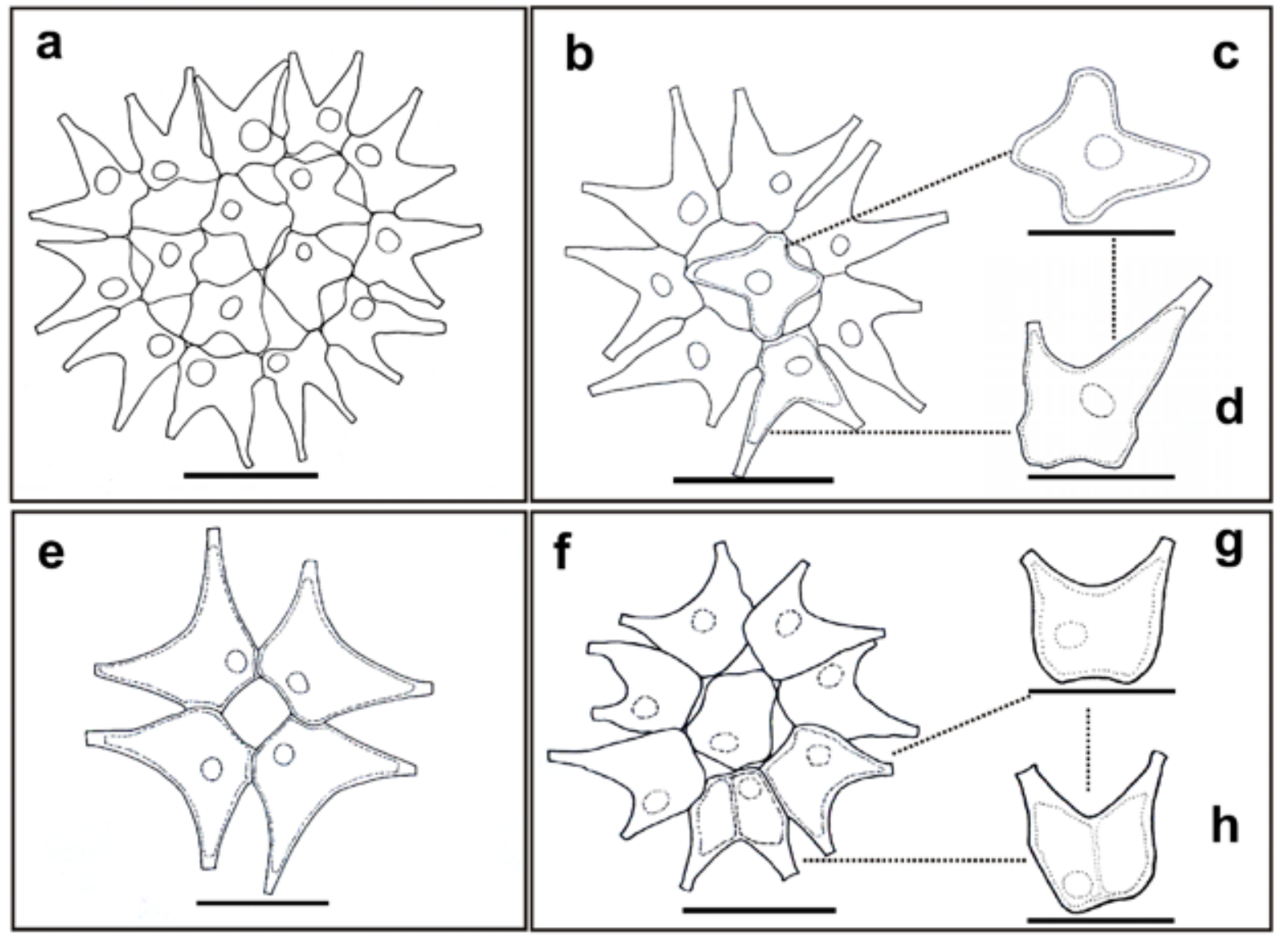

Fig. 8. Drawings of Sorastrum pediastriforme (MJ 2008/46). Scale bar $10 \mu \mathrm{m}$ (a, b, e, f); $6 \mu \mathrm{m}$ (c, d, g, h). (a) iconotype.

different phylogenetic clades (Hegewald \& Wolf 2003; Lewis \& Flechtner 2004; Hegewald et al 2013). In Selenastraceae similar phenotypes such as the needle-shaped or crescent-shaped morphology hide a multitude of phylotypes (FAWLEY et al. 2007; KRIENITZ et al. 2011). In the Hydrodictyaceae members of the genus Pseudopediastrum are characterized both by high morphological diversity and phylogenetic divergence resulting in four new combinations in this study. Regardless of the molecular background that has revealed overwhelming phenotypic diversity of the Hydrodictyaceae, it seems unlikely that more genuslevel diversity will be uncovered. It is suspected that the complicated Pediastrum-like phenotype of most members of this family has evolved infrequently, at best, and independently than easier constructed phenotypes such as spheres which undergo convergent evolution (PotTer et al. 1997; KRIENITZ \& Bock 2012).

Our survey of Pediastrum and related genera from three continents did not provide arguments for endemism of this group, because most of the taxa were found in different geographic regions. Even species formerly known only from tropical or subtropical regions like Monactinus (Pediastrum) simplex extended their distribution area into the temperate zone (Coesel \& Krienitz 2008). The species P. pearsonii known from tropics (KOMÁREK \& JANKOVSKÁ 2001) we found only in Kenya. Probably, this is the exception that proves the rule of cosmopolitan distribution.

\section{Taxonomic conclusions}

Sorastrum pediastriforme JenA et C. BoCK sp. nov. (Figs 2a-d, 9a-h)

Desriptio: Coenobia plus minusve planae multicellularis, 4-8-16 cellulae continens. Cellulae externae per duos lobis formae, rare trilobates. Lobis complanes, elongates cum apicibus coronatis. Cellulae interiorae quadricornutae per foramen inter cellulae. Chloroplastus unicus, parietale, massivus, cum pyrenoido. Propagatio zoosporis.

A speciebus ceteris generis ordine nucleotidorum in $18 S$ and ITS rRNA differt.

Coenobia more or less flat, multicellular, containing 4-8-16 cells. Outer cells two-lobated, seldom trilobated. Lobae elongated with crown-like apices. Inner cells four-lobated with holes between the cells. One parietal, massive chloroplast per cell with a pyrenoid. Propagation by zoospores. The species differs from other species by the order of the nucleotides in SSU and ITS rRNA gene sequences.

Holotype: an air-dried sample of the authentic strain SAG 2392 (MJ 2008/46) deposited at the Botanical Museum at Berlin-Dahlem, Germany under the 
designation B40 0040819.

Iconotype: our Fig. 9a

Authentic strain: SAG 2392 deposited at the Culture Collection of Algae at the University of Göttingen (SAG, Germany).

Type locality: Kenya, dam near Nyahururu Etymology: The species epithet was selected because of the morphological similarity of the colonies to species of the genus Pediastrum.

\section{Monactinus sturmii (Reinsch) JenA et C. Bock comb. nov. \\ Basionym: Pediastrum sturmii Reinsch 1867. Die Algenflora des mittleren Theiles von Franken, p. 90, pl. VII, fig. Ia-d. \\ Synonym: Pediastrum simplex var. sturmii (Reinsch) Wolle 1887.}

Epitype (designated here): An air-dried as well as a formaldehyde-fixed sample of the strain MJ 2009/172, deposited at the Botanical Museum at Berlin-Dahlem under the designation B40 0040814.

Authentic strain: SAG NA2013.007 (MJ 2009/172) deposited at the Culture Collection of Algae at the University of Göttingen (SAG, Germany).

\section{Pseudopediastrum alternans (Nygaard) JENA et C. Bock comb. nov.}

Basionym: Pediastrum alternans Nygaard 1949. Kongl. Dansk Vid. Selskab., Biol. Skr. København, p. 42, fig. 16.

Epitype (designated here): An air-dried sample of the strain MJ 2008/83 deposited at the Botanical Museum at Berlin-Dahlem under the designation B40 0040815. Authentic strain: SAG NA2013.008 (MJ 2008/83) deposited at the Culture Collection of Algae at the University of Göttingen (SAG, Germany).

Pseudopediastrum brevicorne (A. Braun) Jena et C. Bock comb. et stat. nov.

Basionym: Pediastrum boryanum var. brevicorne A. Braun 1855 . Alg. unicell, p. 86, fig. IIB.

Epitype (designated here): An air-dried sample of the strain MJ 2008/28 deposited at the Botanical Museum at Berlin-Dahlem under the designation B40 0040816. Authentic strain: SAG NA2013.009 (MJ 2008/28) deposited at the Culture Collection of Algae at the University of Göttingen (SAG, Germany).

\section{Pseudopediastrum integrum (NäGELI) Jena et C. Bock comb. nov.}

Basionym: Pediastrum integrum Nägeli 1849. Gattungen einzelliger Algen, p. 97, pl. V: B, fig. 4.

Epitype (designated here): An air-dried sample of the strain MJ 2008/86 deposited at the Botanical Museum at Berlin-Dahlem under the designation B40 0040817. Authentic strain: SAG NA2013.010 (MJ 2008/86) deposited at the Culture Collection of Algae at the
University of Göttingen (SAG, Germany). Pseudopediastrum pearsonii (G.S. WEST) JENA et C. Bock comb. nov.

Basionym: Pediastrum pearsonii G.S. West 1912. Ann. S. Afr. Mus. 9, p. 79, figs. 30-32.

Synonym: Pediastrum integrum var. pearsonii (G.S. West) Fritsch in Fritsch et Stephens 1921.

Epitype (designated here): An air-dried sample of the strain KR 2006/01 deposited at the Botanical Museum at Berlin-Dahlem under the designation B40 0040818. Authentic strain: SAG NA2013.011 (KR 2006/01) deposited at the Culture Collection of Algae at the University of Göttingen (SAG, Germany).

ACKNOWLEDGEMENTS

This work was supported in part by a fellowship grant of the German Academic Exchange Service for Mrutyunjay Jena. We thank Reingard Rossberg for joint work at the SEM and Monika Papke for technical assistance.

\section{REFERENCES}

Bock, C.; Pröschold, T. \& Krienitz, L. (2011): Updating the genus Dictyosphaerium and description of Mucidosphaerium gen. nov. (Trebouxiophyceae) based on morphological and molecular data. - J. Phycol. 47: 638-652.

Braun, A. (1855): Algarum unicellularium genera nova vel minus cognita I-III. - 111 pp., W. Engelmann, Leipzig.

Buchheim, M.; Buchieim, J.; Carlson, T.; Braband, A.; Hepperle, D.; Krienitz, L.; Wolf, M. \& Hegewald, E. (2005): Phylogeny of the Hydrodictyaceae (Chlorophyceae): Inferences from rDNA data. - J. Phycol. 41: 1039-1054.

Buchieim, M.A.; Michalopulos, E.A. \& Buchheim, J.A. (2001): Phylogeny of the Chlorophyceae with special reference to the Sphaeropleales: A study of $18 \mathrm{~S}$ and 26S rDNA data. - J. Phycol. 37: 819-835.

Byun, Y. \& Han, K. (2006): PseudoViewer: web application and web service for visualizing RNA pseudoknots and secondary structures. - Nucl. Acids Res. 34: W416-W422.

Coesel, P.F.M. \& Krienitz, L. (2008): Diversity and geographic distribution of desmids and other coccoid green algae. Biodiversity \& Conservation 17: 381-392.

Coleman, A.W. (2003): ITS2 is a double-edged tool for eukaryote evolutionary comparisons. - Trends Genet. 19: 370-735.

Fawley, M.W.; Dean, M.L.; Dimmer, S.K. \& Fawley, K.P. (2005): Evaluating the morphospecies concept in the Selenastraceae (Chlorophyceae, Chlorophyta). - J. Phycol. 42: 142-154.

Gemeinholzer, B.; Droege, G.; Zetsche, H.; Knebelsberger, T.; Raupach, M.; Borsch, T.; KlenK, H.-P.; Haszprunar, G. \& WAEgele, J.W. (2009): DNA Bank Network Webportal.

Hegewald, E. \& Wolf, M. (2003): Phylogenetic relationships of Scenedesmus and Acutodesmus (Chlorophyta, Chlorophyceae) as inferred from 18S rDNA and ITS-2 sequence comparisons. - Plant Syst. Evol. 241: 185-191.

Hegewald, E.; Bock, C. \& Krienitz, L. (2013): Pectinodesmus and the new genera Verrucodesmus and Chodatodesmus (Chlorophyta, Chlorophyceae). - Fottea 13: 149-164.

Hepperle, D. SequentiX Alignment Editor. (2004): Distributed by Author.

HuElsenBECK, J.P. (2002): Testing a covariotide model of DNA substitution. - Mol. Biol. Evol. 19: 698-707.

Huelsenbeck, J. P. \& Ronquist, F. (2001): MRBAYES: Bayesian inference of phylogenetic trees. - Bioinformatics 17: 754755.

KomÁReK, J. \& FotT, B. (1983): Chlorophyceae (Grünalgen) 


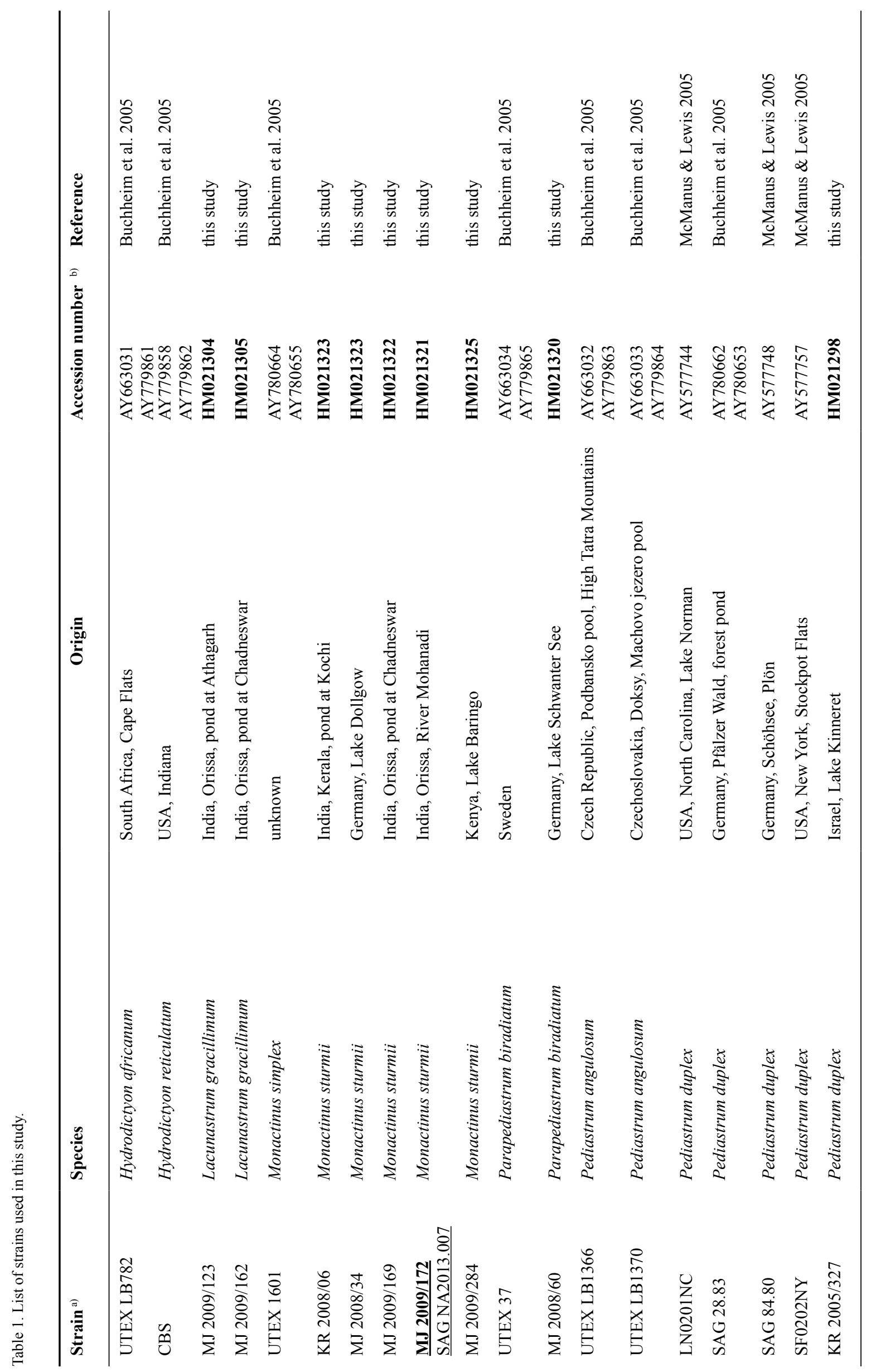




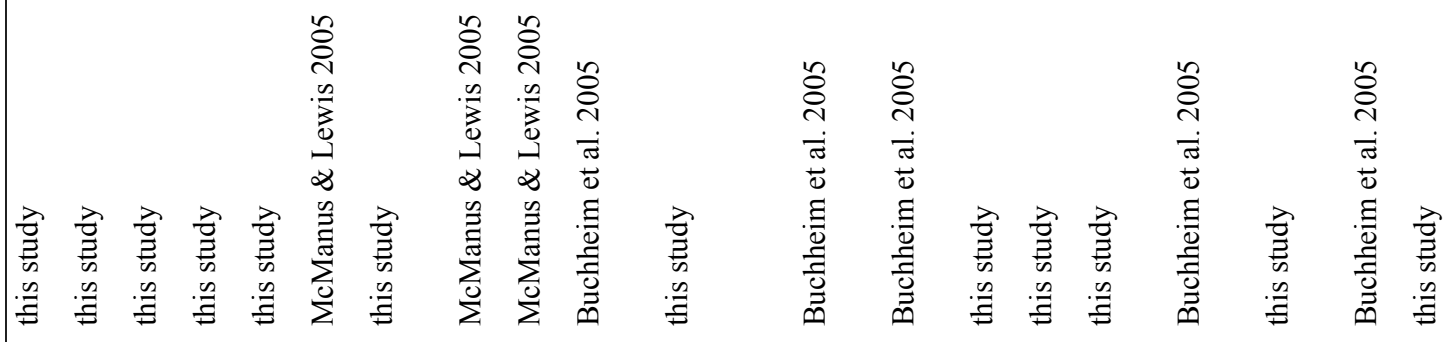

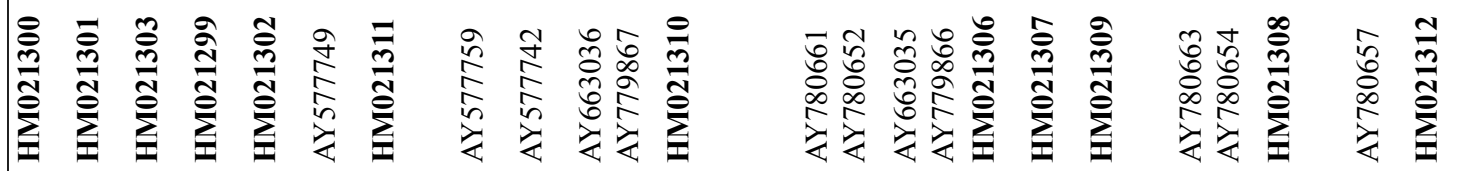

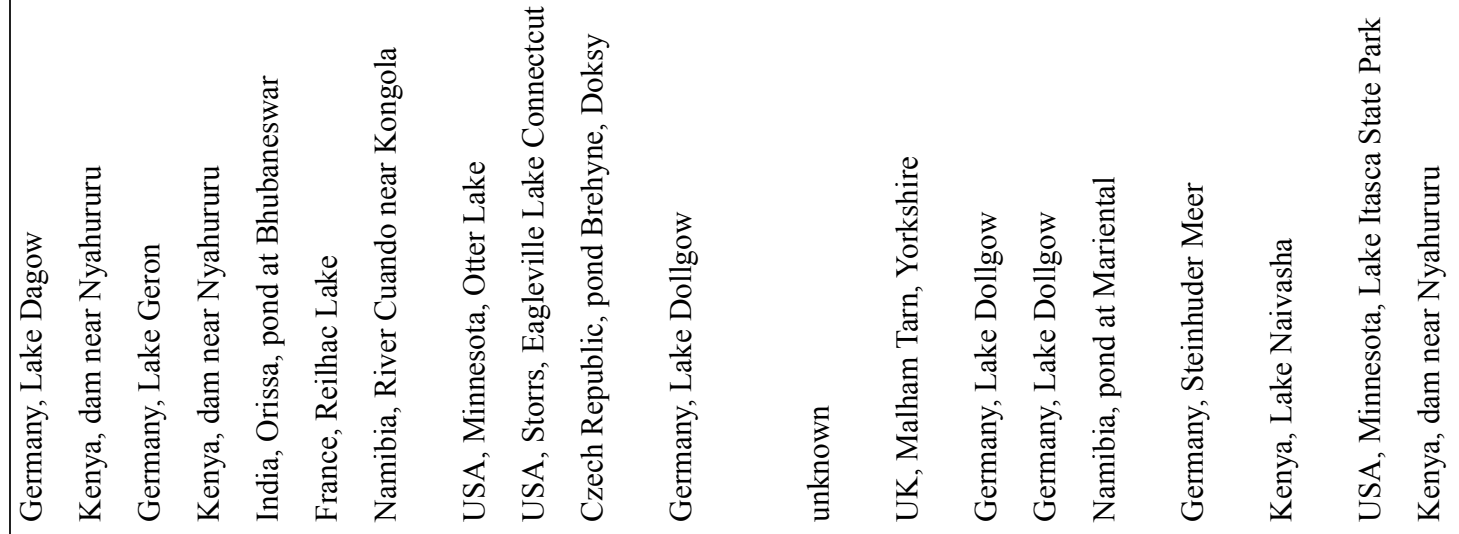

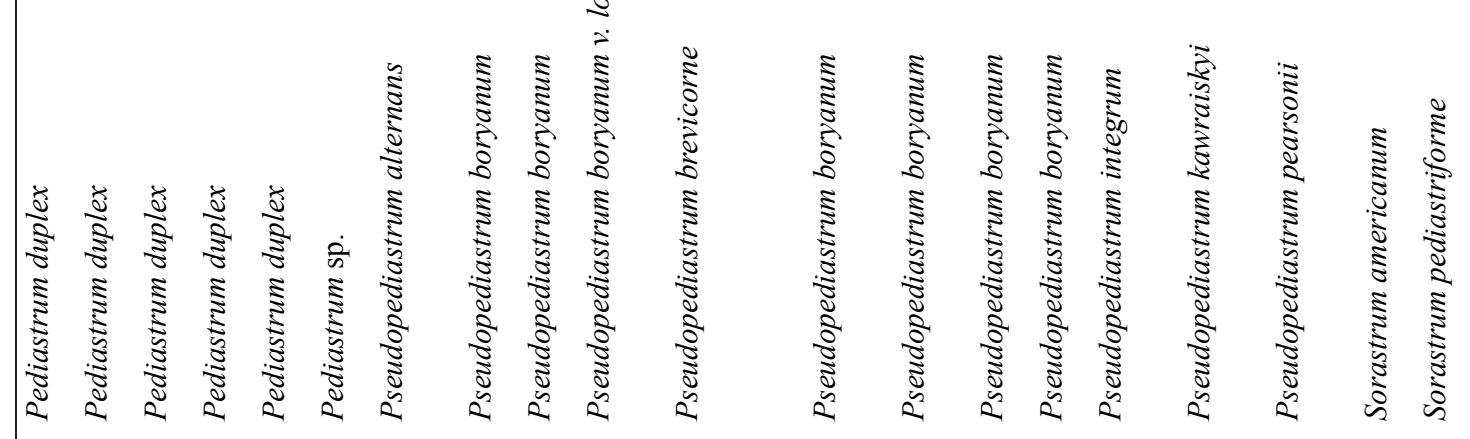

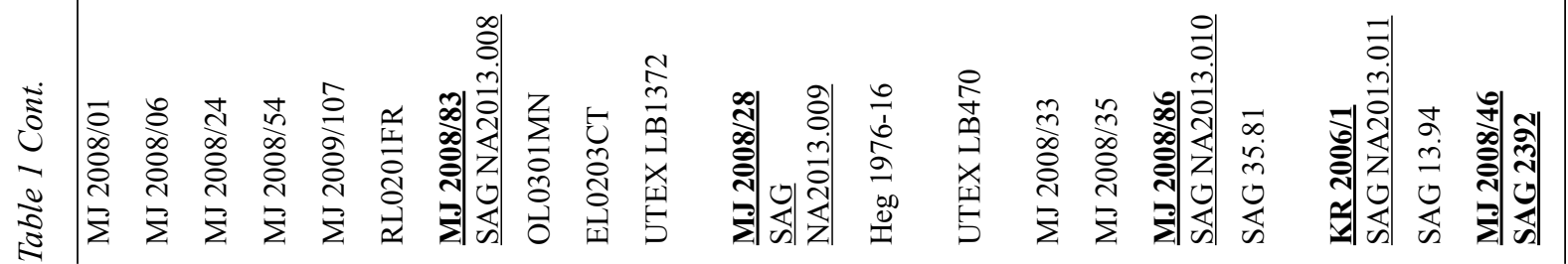




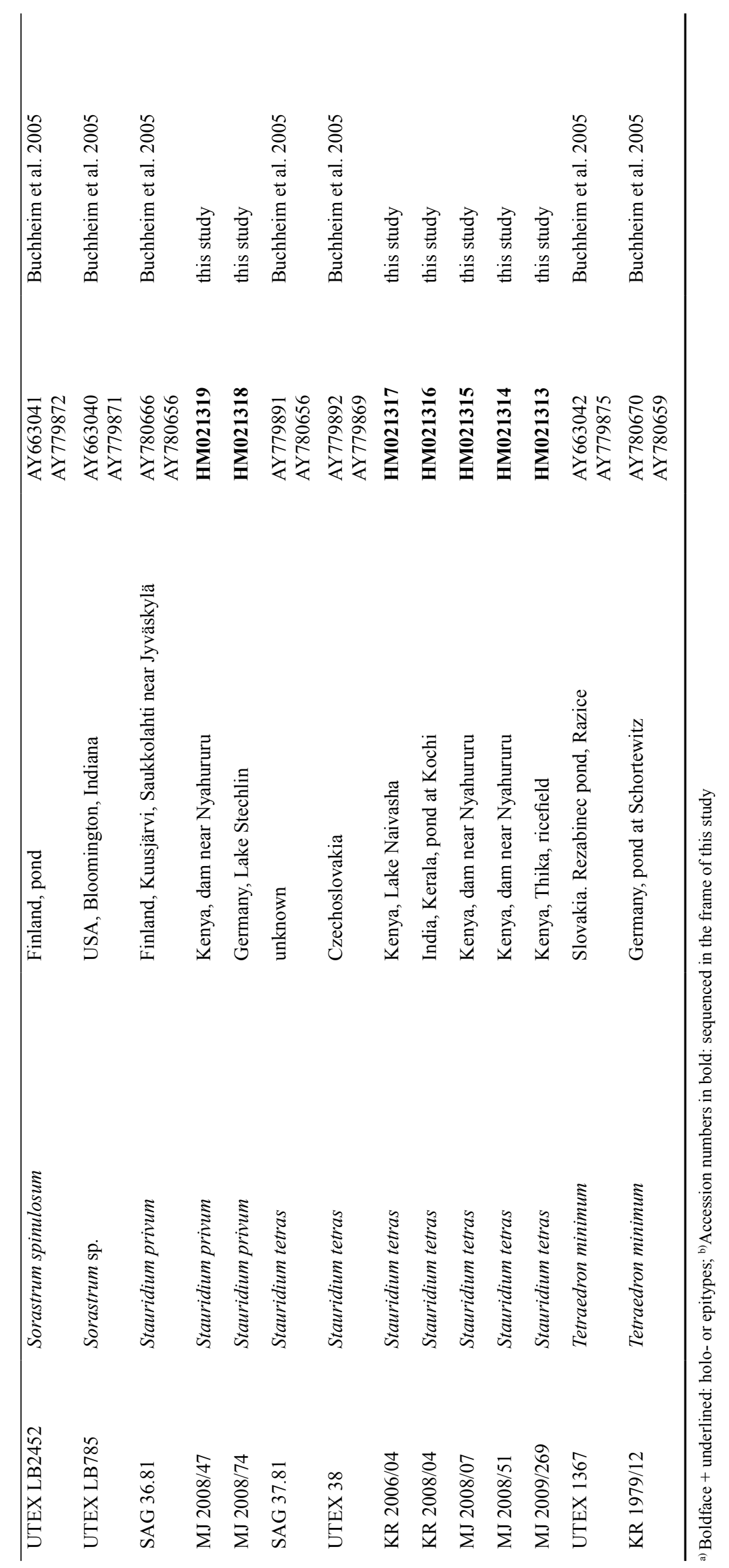


Table 2. Number of CBCs and Hemi-CBCs (in brackets) in conserved regions of ITS-2 of Monactinus.

\begin{tabular}{lllll}
\hline Taxa compared & Helix 1 & Helix II & Helix IIIa & Helix IV \\
\hline UTEX 1601 vs MJ 2008/34 & $0(2)$ & $0(0)$ & $2(5)$ & $0(0)$ \\
UTEX 1601 vs KR 2008/06 & $0(2)$ & $0(0)$ & $2(6)$ & $0(0)$ \\
UTEX 1601 vs MJ 2009/284 & $0(2)$ & $0(0)$ & $2(6)$ & $0(0)$ \\
UTEX 1601 vs MJ 2009/169 & $0(3)$ & $0(0)$ & $2(6)$ & $0(0)$ \\
UTEX 1601 vs MJ 2009/172 & $0(2)$ & $0(0)$ & $2(6)$ & $0(0)$ \\
\hline
\end{tabular}

Table 3. Number of CBCs and Hemi-CBCs (in brackets) in conserved regions of ITS-2 of Pseudopediastrum.

\begin{tabular}{|c|c|c|c|c|}
\hline Taxa compared & Helix 1 & Helix II & Helix III & Helix IV \\
\hline P. boryanum MJ 2008/33 vs $P$. boryanum $\mathrm{Hg}$ 1976-16 & $0(0)$ & $0(0)$ & $0(0)$ & $0(0)$ \\
\hline MJ 2008/33 vs $P$. boryanum var. cornutum (UTEX 470) & $0(2)$ & $0(0)$ & $0(0)$ & $0(0)$ \\
\hline MJ 2008/33 vs $P$. kawraiskyi 35.81 & $0(1)$ & $0(1)$ & $2(0)$ & $0(0)$ \\
\hline MJ 2008/33 vs MJ 2008/35 & $0(0)$ & $0(0)$ & $0(0)$ & $0(1)$ \\
\hline MJ 2008/33 vs MJ 2008/86 & $0(1)$ & $0(0)$ & $0(3)$ & $0(0)$ \\
\hline MJ 2008/33 vs KR 2006/01 & $1(1)$ & $0(1)$ & $1(2)$ & $0(0)$ \\
\hline MJ 2008/33 vs MJ 2008/83 & $1(2)$ & $0(1)$ & $0(3)$ & $0(1)$ \\
\hline MJ 2008/33 vs MJ 2008/28 & $1(0)$ & $0(1)$ & $0(4)$ & $0(1)$ \\
\hline P. alternans MJ 2008/83 vs $P$. boryanum $\mathrm{Hg}$ 1976-16 & $1(2)$ & $0(1)$ & $0(3)$ & $0(1)$ \\
\hline MJ 2008/83 vs $P$. boryanum var. cornutum (UTEX 470) & $0(4)$ & $0(1)$ & $0(3)$ & $0(1)$ \\
\hline MJ 2008/83 vs $P$. kawraiskyi 35.81 & $0(1)$ & $0(2)$ & $1(2)$ & $0(0)$ \\
\hline MJ 2008/83 vs MJ 2008/28 & $0(3)$ & $0(0)$ & $0(1)$ & $0(0)$ \\
\hline P. brevicorne MJ 2008/28 vs $P$. boryanum $\mathrm{Hg}$ 1976-16 & $1(0)$ & $0(1)$ & $0(4)$ & $0(1)$ \\
\hline MJ 2008/28 vs $P$. boryanum var. cornutum UTEX 470 & $1(2)$ & $0(1)$ & $0(4)$ & $0(1)$ \\
\hline MJ 2008/28 vs $P$. kawraiskyi 35.81 & $0(4)$ & $0(2)$ & $2(1)$ & $0(0)$ \\
\hline P. integrum MJ 2008/86 vs P. boryanum Hg 1976-16 & $1(1)$ & $0(0)$ & $0(3)$ & $0(0)$ \\
\hline MJ 2008/86 vs $P$. boryanum var. cornutum UTEX 470 & $0(3)$ & $0(0)$ & $0(3)$ & $0(0)$ \\
\hline MJ 2008/86 vs $P$. kawraiskyi 35.81 & $0(0)$ & $0(1)$ & $2(1)$ & $0(0)$ \\
\hline MJ 2008/86 vs KR 2006/01 & $1(0)$ & $0(1)$ & $1(1)$ & $0(0)$ \\
\hline MJ 2008/86 vs MJ 2008/83 & $1(1)$ & $0(1)$ & $0(2)$ & $0(0)$ \\
\hline MJ 2008/86 vs MJ 2008/28 & $0(4)$ & $0(1)$ & $0(4)$ & $0(0)$ \\
\hline
\end{tabular}


Table 3 Cont.

\begin{tabular}{lllll}
\hline P. pearsonii KR 2006/01 vs P. boryanum Hg 1976-16 & $1(1)$ & $0(1)$ & $1(2)$ & $0(0)$ \\
KR 2006/01 vs P. boryanum var. cornutum UTEX 470 & $1(3)$ & $0(1)$ & $1(2)$ & $0(0)$ \\
KR 2006/01 vs P. kawraiskyi 35.81 & $1(0)$ & $0(2)$ & $2(0)$ & $0(0)$ \\
KR 2006/01 vs MJ 2008/83 & $1(1)$ & $0(1)$ & $1(1)$ & $0(0)$ \\
KR 2006/01 vs MJ 2008/28 & $1(2)$ & $0(0)$ & $1(1)$ & $0(0)$ \\
\hline
\end{tabular}

Ordnung: Chlorococcales. - In: Huber-Pestalozzi, G. (ed.): Das Phytoplankton des Süßwassers 7. Teil, 1. Hälfte. - 1044 pp., E. Schweizerbart'sche Verlagsbuchhandlung (Nägele u. Obermiller), Stuttgart.

KomÁrek, J. \& JanKovSKÁ, V. (2001): Review of the green algal genus Pediastrum; implication for pollenanalytical research. - Bibl. Phycol. 108: 1-127.

Krienitz, L. \& Bock, C. (2012): Present state of the systematics of planktonic coccoid green algae of inland waters. Hydrobiologia 698: 295-326.

Krienitz, L.; Bock, C.; Nozaki, H. \& Wolf, M. (2011): SSU rRNA gene phylogeny of morphospecies affiliated to the bioassay alga "Selenastrum capricornutum" recovered the polyphyletic origin of crescent-shaped Chlorophyta. - J. Phycol. 47: 880-893.

Krienitz, L.; Bock, C.; Kotut, K. \& Pröschold, T. (2012): Genotypic diversity of Dictyosphaerium-morphospecies (Chlorellaceae, Trebouxiophyceae) in African inland waters, including the description of four new genera. Fottea 12: 231-253.

LewIs, L.A. (1997): Diversity and phylogenetic placement of Bracteacoccus Tereg (Chlorophyceae, Chlorophyta) based on ribosomal RNA gene sequence data. - J. Phycol. 33: 279-285.

Lewis, L.A. \& Flechtner, V.R. (2004): Cryptic species of Scenedesmus (Chlorophyta) from desert soil communities of western North America. - J. Phycol. 40: 1127-1137.

McFadden, G.I. \& Melkonian, M. (1986). Use of Hepes buffer for microalgal culture media and fixation for electron microscopy. - Phycologia 25: 551-557.

McManus, H.A. \& Lewis, L.A. (2005): Molecular phylogenetics, morphological variation and colony-form evolution in the family Hydrodictyaceae (Sphaeropleales, Chlorophyta). Phycologia 44: 582-595.

McManus, H.A. \& Lewis, L.A. (2011): Molecular phylogenetic relationships in the freshwater family Hydrodictyaceae (Sphaeropleales, Chlorophyceae), with an emphasis on Pediastrum duplex. - J. Phycol. 47: 152-163.

McManus, H.A.; Lewis, L.A. \& Schultz, E.T. (2011): Distinguishing multiple lineages of Pediastrum duplex with morphometrics and a proposal for Lacunastrum gen. nov. - J. Phycol. 47: 123-130.

NäGELI, C. (1849): Gattungen einzelliger Algen. - 139 pp., Friedrich Schulthess, Zürich, Switzerland.

NygaARd, G. (1949): Hydrobiological studies on some Danish ponds and lakes. - Kongl. Dansk Vid. Selskab., Biol. Skr. KØbenhavn 7:1-293.

Parra, C.O. (1979): Revision der Gattung Pediastrum Meyen (Chlorophyta). - Bibl. Phycol. 48: 1-83.

Potter, D.; Lajeunesse, T.C.; Saunders, G.W. \& Anderson, R.A. (1997): Convergent evolution masks extensive biodiversity among marine coccoid picoplankton. - Biodiversity \& Conservation 6: 99-107.

Reinsch, P.F. (1867): Die Algenflora des mittleren Theiles von Franken. - Abh. Naturforsch. Ges. Nürnberg 1866: 1-238.

Schultz, J. \& Wolf, M. (2009): ITS2 sequence-structure analysis in phylogenetics: A how-to manual for molecular systematics. - Mol. Phyl. Evol. 52: 250-252.

Seibel, P. N.; Dandekar, T.; Müller, T. \& Wolf, M. (2008):
Synchronous visual analysis and editing of RNA sequence and secondary structure alignments using 4SALE. - BMC Res. Notes 91: 1-7.

Seibel, P. N.; Müller, T.; Dandekar, T.; Schultz, J. \& Wolf, M. (2006): 4SALE - A tool for synchronous RNA sequence and secondary structure alignment and editing. - BMC Bioinf. 7: 498.

SwOFFord, D.L. (2002): Phylogenetic analysis using parsimony (* and other methods), PAUP version 4.0b 10. 2003. Massachusetts, Sinauer Associates, Sunderland.

Vanormelingen, P.; Hegewald, E.; Braband, A.; Kitschke, M.; Friedl, T.; Sabbe, K. \& Vyverman, W. (2007): The systematics of a small spineless Desmodesmus species, D. costato-granulatus (Sphaeropleales, Chlorophyceae), based on ITS2 rDNA sequence analyses and cell wall morphology. - J. Phycol. 43: 378-396.

West, G.S. (1912): Percy Sladen memorial expedition in SouthWest Africa, 1908-1911. Report No. 14. Fresh-water algae. - Ann. S. Afr. Mus. 9: 61-90.

Wilcox, L.W.; Lewis, L.A.; Fuerst, P.A. \& Floyd, G.L. (1992): Assessing the relationships of autosporic and zoosporic chlorococcalean green algae with $18 \mathrm{~S}$ rDNA sequence data. - J. Phycol. 28: 381-406.

ZuKer, M. (2003): Mfold web server for nucleic acid folding and hybridization prediction. - Nucl. Acids Res. 31: 3406-3415.

(C) Czech Phycological Society (2014)

Received September 13, 2013

Accepted December 18, 2013 